\title{
Recent developments in the Dutch firm-size distribution
}

Citation for published version (APA):

Carree, M., \& Thurik, R. (1991). Recent developments in the Dutch firm-size distribution. Small Business Economics, 3, 261-268. https://doi.org/10.1007/BF01840608

Document status and date:

Published: 01/12/1991

DOI:

10.1007/BF01840608

Document Version:

Publisher's PDF, also known as Version of record

\section{Please check the document version of this publication:}

- A submitted manuscript is the version of the article upon submission and before peer-review. There can be important differences between the submitted version and the official published version of record.

People interested in the research are advised to contact the author for the final version of the publication, or visit the DOI to the publisher's website.

- The final author version and the galley proof are versions of the publication after peer review.

- The final published version features the final layout of the paper including the volume, issue and page numbers.

Link to publication

\footnotetext{
General rights rights.

- You may freely distribute the URL identifying the publication in the public portal. please follow below link for the End User Agreement:

www.umlib.nl/taverne-license

Take down policy

If you believe that this document breaches copyright please contact us at:

repository@maastrichtuniversity.nl

providing details and we will investigate your claim.
}

Copyright and moral rights for the publications made accessible in the public portal are retained by the authors and/or other copyright owners and it is a condition of accessing publications that users recognise and abide by the legal requirements associated with these

- Users may download and print one copy of any publication from the public portal for the purpose of private study or research.

- You may not further distribute the material or use it for any profit-making activity or commercial gain

If the publication is distributed under the terms of Article $25 \mathrm{fa}$ of the Dutch Copyright Act, indicated by the "Taverne" license above, 


\section{Recent Developments in the Dutch Firm-Size Distribution*}

\begin{abstract}
This study investigates the development of the firm-size distribution in the Netherlands using various measures. Data are used for the period 1978 through 1989 covering practically the entire Dutch private sector. The results show a general tendency towards smaller firm sizes in manufacturing industries until 1986, but indicate an opposite development after that year. This tendency towards larger firm sizes after 1986 is also encountered for non-manufacturing industries.
\end{abstract}

\section{Introduction}

It is often suggested that the share of small firms in Western economies has risen during the last years. Carlsson (1989) presents empirical evidence for this proposition in manufacturing, and engineering industries in particular, in several Western industrial countries. ${ }^{1}$ The purpose of the present study is to investigate the development of the Dutch firm-size distribution for manufacturing and nonmanufacturing industries for the years 1978 through 1989 with the intention to make an international comparison of firm-size distributions across countries. We do not confine our investiga-

Martin Carree

Econometric Institute

Erasmus University Rotterdam

P.O. Box 1738

3000 DR Rotterdam

The Netherlands

Roy Thurik

Econometric Institute

Erasmus University Rotterdam

P.O. Box 1738

3000 DR Rotterdam

The Netherlands

and

Research Institute for Small and Medium-Sized Business

P.O. Box 7001

2701 AA Zoetermeer

The Netherlands tion to the location of the firm-size distribution, as measured by average firm size, but we shall also use measures of other aspects of the shape of this distribution.

This study is organized as follows: In Section 2 the data of the Dutch industries are discussed and in Section 3 the measures of the firm-size distribution are described and average results for the industries are given. The development of firm-size distributions among manufacturing and non-manufacturing industries from 1978 until 1989 is discussed in Section 4. Section 5 is used for a closer look at the turning point in the average firm size for the seperate industries and Section 6 is used for discussion.

\section{Data}

The data for the Dutch industries are derived from two files of the Netherlands Central Bureau of Statistics, viz., "Statistics of Enterprises" and "Statistics of Man-years and Gross Wages", respectively. The first data set contains the number of firms with 1 to 10 employees $^{2}$ (group 1), 11 to 50 employees (group 2), 51 to 100 employees (group 3) and 100 or more employees (group 4) for 16 manufacturing and 15 non-manufacturing industries for the years 1978 through 1989. The second data set contains the number of employees corresponding to the same groups and industries, but only for the years 1978, 1981, 1984 and 1987. ${ }^{3}$ Both data files are elaborated by the Research Institute for Small and Medium-Sized Business. In Table I the 31 industries are given. The first 16 industries (ISIC 31-39) are manufacturing industries and the last 15 industries are non-manufacturing industries (ISIC 50-951). In addition, Table I displays the relative contribution of the industries to the number of firms and employees. The data cover 31 of the 36 industries of

Small Business Economics 3: 261-268, 1991.

(C) 1991 Kluwer Academic Publishers. Printed in the Netherlands. 
TABLE I

Description of the industries

\begin{tabular}{|c|c|c|c|c|c|}
\hline No. & ISIC & SBI & Industry & $\begin{array}{l}\text { No. } \\
\text { Firms }\end{array}$ & $\begin{array}{l}\text { No. } \\
\text { Empl. } \\
(\times 1000)\end{array}$ \\
\hline 1. & 31 & 20,21 & Manufacture of food, beverages and tobacco products & 6,974 & 161 \\
\hline 2. & 321 & 22 & Manufacture of textiles & 814 & 38 \\
\hline 3. & 322 & 23 & Wearing apparel, except footwear & 1,143 & 21 \\
\hline 4. & $323 / 4$ & 24 & Manufacture of leather, footwear and other leather products & 542 & 9 \\
\hline 5. & 33 & 25 & Manufacture of wood products, including furniture & 3,540 & 44 \\
\hline 6. & 341 & 26 & Manufacture of paper and paper products & 282 & 25 \\
\hline 7. & 342 & 27 & Printing, publishing and allied industries & 2,637 & 65 \\
\hline 8. & $351 / 2$ & 29,30 & $\begin{array}{l}\text { Chemical industry and manufacture of artificial and synthetic filaments } \\
\text { and staple fibres }\end{array}$ & 562 & 85 \\
\hline 9. & $355 / 6$ & 31 & Manufacture of rubber and plastic products & 569 & 25 \\
\hline 10 . & 36 & 32 & Manufacture of building materials, earthenware, glass and glass products & 1,240 & 37 \\
\hline 11. & 381 & 34 & $\begin{array}{l}\text { Manufacture of fabricated metal products, except machinery and transport } \\
\text { equipment }\end{array}$ & 5,100 & 93 \\
\hline 12. & 382 & 35 & Mechanical engineering & 2,033 & 85 \\
\hline 13. & 383 & 36 & Electrical engineering & 474 & 109 \\
\hline 14. & 384 & 37 & Manufacture of transport equipment & 1,539 & 71 \\
\hline 15. & 385 & 38 & Instrument engineering & 597 & 12 \\
\hline 16. & 39 & 39 & Other manufacturing industries & 477 & 7 \\
\hline 17. & 50 & 51 & Construction & 21,188 & 300 \\
\hline 18. & 50 & 52 & Installation on construction projects & 6,781 & 82 \\
\hline 19. & 61 & $61-64$ & Wholesale trade, merchandise and commodity brokers and agents & 23,222 & 284 \\
\hline 20. & 62 & 65,66 & Retail trade & 43,759 & 282 \\
\hline 21. & 63 & 67 & Hotels, restaurants and cafes etc. & 14,817 & 61 \\
\hline 22. & 711 & 71,72 & Railways and road transport & 7,136 & 113 \\
\hline 23. & $7121 / 3$ & 73 & Sea transport & 399 & 34 \\
\hline 24. & 719 & 76 & Supporting services to transport & 1,342 & 24 \\
\hline 25. & 81 & 81 & Banking and finance & 2,525 & 104 \\
\hline 26. & 82 & 82 & Insurance & 2,479 & 49 \\
\hline 27. & 831 & 83 & Real estate etc. & 4,121 & 25 \\
\hline 28. & 832 & 84 & Business services & 12,899 & 194 \\
\hline 29. & 833 & 85 & Renting of machines and other movables & 478 & 4 \\
\hline 30. & 9 & 9 & Other services & 31,684 & 514 \\
\hline 31. & 951 & 68 & Repair of consumer goods & 7,971 & 66 \\
\hline
\end{tabular}

Note: For the ISIC-code the 'International Standard Industrial Classification' of 1974 (revision 2) is used. For the SBI-code the 'Standaard Bedrijfsindeling' of the Central Bureau of Statistics (CBS) is used. The figures for the number of firms and employees (in thousands) refer to 1978.

Source: Central Bureau of Statistics and Research Institute for Small and Medium-Sized Business.

the Dutch private sector and represent $47.1 \%$ of the total number of firms when firms without employees (approx. 470,000) are included and $99.3 \%$ of the total number of firms when firms without employees (approx. 220,000) are excluded (figures of 1987). The 31 industries cover $91.3 \%$ of total labour volume (approx. 3.7 million f.t.e.'s) in the private sector in 1987.

\section{Measuring firm-size distributions}

The firm-size distributions are compared for each of the 31 industries using measures of the location and shape. The location of a firm-size distribution is measured by its mean. To describe the shape of a firm-size distribution, we use three measures of the lack of symmetry around the mean. Apart 
from the skewness of the distribution and the ratio of the number of small over large firms, we also incorporate the parameter of a discrete Pareto distribution. Generally, the discrete Pareto distribution resembles observed firm-size distributions of industries with low entry barriers rather well (see Ijiri and Simon, 1977). Its parameter is the determinant of the shape of the distribution. Next to these measures concerning the firm-size distribution, a measure of concentration, the Ginicoefficient, is incorporated. We use this measure to compare developments in the firm-size distribution with developments in concentration. The Gini-coefficient can however neither be directly interpreted as a measure of the location nor of the shape of a firm-size distribution.

In order to define the respective measures of the firm-size distribution and the Gini-coefficient, we use the variables $T E$, the total number of employees in an industry, $T F$, the total number of firms in an industry, $f_{i}$, the number of firms in group $i$ divided by $T F$, and $\mu_{i}$, the number of employees in group $i$ divided by the number of firms in group $i$. The five measures can now be defined as follows:

1. $\mu=\sum_{i} f_{i} \mu_{i}=T E / T F$.

The variable $\mu$ is used to describe the location of firm-size distributions and is equal to the average number of employees per firm in an industry. A decreasing value of $\mu$ points to a greater importance of small-sized firms.

2. $\left.S K E W=\left(\sum_{i} f_{i} \mu_{i}^{3}-3 \mu \sum_{i} f_{i} \mu_{i}^{2}+2 \mu^{3}\right)\right)$

$$
\left(\sum_{i} f_{i} \mu_{i}^{2}-\mu^{2}\right)^{1.5}
$$

The variable $S K E W$ is equal to the skewness of a discrete distribution with probabilities $f_{i}$ on the occurrence of $\mu_{i}(i=1, \ldots, 4)$. This skewness is represented by the ratio of the third central moment over the third power of the standard deviation. A high value of SKEW indicates a right-skewed distribution and this implies a high share of small firms in terms of employment. An increasing value of SKEW means that a greater share of employment is shifted to the smaller firms.

3. the estimated parameter $\rho$ of a discrete Pareto distribution.

The discrete Pareto distribution has a cumulative distribution function $F(j)=1-j^{-\rho}$ for $j=1,2,3, \ldots$ We choose $\rho$ in such way that the Pearson chi-square, $4 \cdot \Sigma_{i}\left(f_{i}-\xi_{i}\right)^{2} / \xi_{i}$, is minimized ${ }^{4}$ with $\xi_{i}$ as the theoretical share of firms in each group:

$$
\begin{aligned}
& \xi_{1}=F(10)=1-10^{-\rho}, \\
& \xi_{2}=F(50)-F(10)=10^{-\rho}-50^{-\rho}, \\
& \xi_{3}=F(100)-F(50)=50^{-\rho}-100^{-\rho}, \\
& \xi_{4}=1-F(100)=100^{-\rho} .
\end{aligned}
$$

In the case of low entry barriers observed firmsize distributions generally have a shape like the discrete Pareto distribution. A high value of $\rho$ implies a high share of small firms.

4. $M_{14}=f_{1} / f_{4}$.

The variable $M_{14}$ is equal to the ratio of the number of firms in group 1 over the number of firms in group 4. A rise in the value of $M_{14}$ indicates a relative shift towards more smallsized firms.

$$
\text { 5. GINI= } \begin{aligned}
& (T F / T E) \cdot\left(f_{1}^{2} \mu_{1}+f_{2}^{2} \mu_{2}+f_{3}^{2} \mu_{3}+f_{4}^{2} \mu_{4}\right. \\
& +2 f_{1} f_{2} \mu_{1}+2 f_{1} f_{3} \mu_{1}+2 f_{1} f_{4} \mu_{1}+2 f_{2} f_{3} \mu_{2} \\
& \left.+2 f_{2} f_{4} \mu_{2}+2 f_{3} f_{4} \mu_{3}\right)-1 .
\end{aligned}
$$

The Gini-coefficient, ${ }^{5}$ denoted by GINI, is incorporated in our analysis as a commonly used measure of concentration. The value of GINI is between 0 and 1 , where a higher value indicates a higher concentration in terms of employment.

The first four measures cover a wide range of aspects of the firm-size distribution, but are probably highly correlated. Clearly, higher values of $\mu$ and low values of $S K E W, \rho$ and $M_{14}$ will tend to coincide because all are indicators of the share of small firms. The use of different measures does however provide more information about the 
extent of the asymmetry of the firm-size distribution.

In Table II the averages of $\mu, S K E W, \rho, M_{14}$ and GINI over the period 1978-1989 are presented for the 31 industries. In general, the values of $\mu$ and GINI are higher and the values of SKEW, $\rho$ and $M_{14}$ lower for the manufacturing industries (ISIC 31-39) than for the non-manufacturing industries (ISIC 50-951). This indicates that manufacturing industries are more large-scaled. ${ }^{6}$

Using a chi-square goodness-of-fit test, we find that the hypothesis of a discrete Pareto distribution has to be rejected in most cases. This can be

TABLE II

Average values of $\mu, S K E W, \rho, M_{14}$ and GINI

\begin{tabular}{lrrlrr}
\hline ISIC & \multicolumn{1}{c}{$\bar{\mu}$} & $\overline{S K E W}$ & $\bar{\rho}$ & $\bar{M}_{14}$ & $\overline{G I N I}$ \\
\hline 31 & & & & & \\
\hline 321 & 24.0 & 4.5 & 0.894 & 19.0 & 0.776 \\
322 & 42.1 & 2.5 & 0.713 & 5.7 & 0.730 \\
$323 / 4$ & 17.8 & 3.8 & 0.828 & 22.4 & 0.693 \\
33 & 16.3 & 3.6 & 0.817 & 30.4 & 0.642 \\
341 & 11.9 & 5.4 & 0.868 & 61.9 & 0.599 \\
342 & 82.7 & 1.1 & 0.606 & 1.4 & 0.626 \\
$351 / 2$ & 21.5 & 4.2 & 0.814 & 16.5 & 0.709 \\
$355 / 6$ & 151.8 & 1.4 & 0.630 & 2.0 & 0.734 \\
36 & 37.3 & 3.0 & 0.684 & 7.2 & 0.688 \\
381 & 31.2 & 3.5 & 0.720 & 9.8 & 0.707 \\
382 & 18.9 & 4.4 & 0.817 & 20.4 & 0.681 \\
383 & 36.5 & 2.9 & 0.679 & 6.4 & 0.674 \\
384 & 173.5 & 2.4 & 0.712 & 4.9 & 0.842 \\
385 & 48.4 & 3.7 & 0.775 & 10.6 & 0.822 \\
39 & 15.9 & 4.8 & 0.884 & 27.7 & 0.692 \\
50 & 15.7 & 4.7 & 0.886 & 25.5 & 0.702 \\
50 & 12.7 & 6.3 & 0.885 & 47.7 & 0.623 \\
61 & 10.8 & 7.5 & 0.939 & 71.1 & 0.600 \\
62 & 11.3 & 6.8 & 0.926 & 59.4 & 0.625 \\
63 & 6.5 & 15.1 & 1.251 & 224.9 & 0.601 \\
711 & 4.1 & 14.8 & 1.354 & 322.2 & 0.470 \\
$7121 / 3$ & 16.1 & 9.5 & 0.880 & 74.3 & 0.698 \\
719 & 14.5 & 2.2 & 0.654 & 3.5 & 0.751 \\
81 & 15.6 & 5.2 & 0.876 & 32.2 & 0.676 \\
82 & 56.5 & 5.2 & 0.772 & 18.8 & 0.864 \\
831 & 19.8 & 5.6 & 1.060 & 31.2 & 0.836 \\
832 & 5.6 & 8.5 & 1.165 & 206.1 & 0.556 \\
833 & 14.2 & 6.8 & 1.005 & 44.5 & 0.753 \\
9 & 7.7 & 9.2 & 1.108 & 107.1 & 0.604 \\
951 & 15.9 & 5.4 & 1.012 & 29.9 & 0.809 \\
& 7.1 & 8.3 & 1.005 & 294.4 & 0.489
\end{tabular}

Note: The variables $\bar{\mu}, \overline{S K E W}, \bar{\rho}, \bar{M}_{14}$ and $\overline{G I N I}$ represent the average values of $\mu, S K E W, \rho, M_{14}$ and GINI over the period 1978-1989. attributed either to high entry barriers or to the large number of firms, which makes it difficult to test a point hypothesis of a fixed distribution to a continuum of distributions. In the former case, the value of $\rho$ has to be interpreted carefully.

\section{The development of measures}

In this section we investigate the development of the five measures over the years 1978-1989. In Table III the percentage changes of $\mu, S K E W, \rho$, $M_{14}$ and $G I N I$ are presented. A negative value of $\% \Delta \mu$ and positive values of $\% \Delta S K E W, \% \Delta \rho$ and

TABLE III

Development of $\mu, S K E W, \rho, M_{14}$ and GINI

\begin{tabular}{lrrrrr}
\hline ISIC & $\% \Delta \mu$ & $\% \Delta S K E W$ & $\% \Delta \rho$ & $\% \Delta M_{14}$ & $\% \Delta G I N I$ \\
\hline 31 & +10.0 & -0.6 & -4.1 & -6.1 & -1.7 \\
321 & -36.4 & +48.9 & +6.9 & +105.1 & -0.4 \\
322 & -42.8 & +22.7 & +14.5 & +130.7 & -1.8 \\
$323 / 4$ & -17.6 & +23.9 & +6.1 & +71.4 & +1.6 \\
33 & -15.7 & +11.7 & -1.9 & +96.3 & -6.9 \\
341 & -3.5 & -5.5 & +2.5 & +10.2 & +0.5 \\
342 & -18.0 & +22.1 & +8.1 & +53.1 & +0.3 \\
$351 / 2$ & +7.2 & -15.0 & -3.4 & -23.8 & -3.9 \\
$355 / 6$ & -21.7 & +20.2 & +4.6 & +49.0 & +0.8 \\
36 & -5.5 & +12.5 & +0.5 & +12.3 & +0.3 \\
381 & +2.5 & -3.3 & -7.5 & -2.1 & -6.1 \\
382 & -26.5 & +23.1 & +1.7 & +61.3 & -5.8 \\
383 & -52.6 & +58.6 & +10.3 & +119.5 & +6.6 \\
384 & -6.5 & +4.8 & -1.7 & +2.5 & -0.6 \\
385 & -34.1 & +40.3 & +0.6 & +122.0 & -9.8 \\
39 & +6.0 & +9.1 & +2.1 & -6.8 & +10.7 \\
50 & -3.9 & -7.3 & -2.1 & -0.9 & -3.0 \\
50 & +0.1 & +6.0 & -2.7 & +9.4 & -1.6 \\
61 & -10.8 & +10.4 & +3.3 & +24.6 & -3.1 \\
62 & +13.1 & -1.3 & +1.8 & -5.8 & +6.8 \\
63 & +17.5 & +3.3 & -4.1 & -16.0 & +5.2 \\
711 & +6.2 & -15.9 & -6.1 & -28.9 & -3.3 \\
$7121 / 3$ & -15.5 & +5.4 & -1.2 & +1.5 & -2.2 \\
719 & -13.6 & +23.6 & +0.2 & +67.1 & -6.7 \\
81 & +35.6 & -13.9 & -6.6 & -27.0 & +1.8 \\
82 & +7.3 & +13.2 & +6.1 & +26.5 & +2.9 \\
831 & +14.6 & -41.4 & -8.2 & -5.8 & +4.3 \\
832 & +28.7 & -6.4 & -0.6 & -17.2 & +11.7 \\
833 & +9.9 & +33.6 & -3.9 & +39.8 & +3.2 \\
9 & +14.2 & -5.1 & -1.1 & -10.6 & +3.1 \\
951 & -18.1 & -1.5 & +3.0 & +147.8 & -12.7 \\
& & & & & \\
\hline & & & & &
\end{tabular}

Note: The variables $\% \Delta \mu, \% \Delta S K E W, \% \Delta \rho, \% \Delta M_{14}$ and $\% \triangle G I N I$ represent percentual changes over the period 1978-1989 for $\mu, S K E W, \rho, M_{14}$ and GINI. 
$\% \Delta M_{14}$ point at a growing share of smaller firms. We see that this is the case for most manufacturing industries (ISIC 31-39). ${ }^{7}$ For the non-manufacturing industries (ISIC 50-951) there is no clear overall image of the development of these four measures. The group of industries of financial and business services (ISIC 81-833), however, clearly shows a growing average firm size.

If a higher share of small firms and lower values of concentration would coincide, we would expect negative values for $\% \Delta G I N I$ when the value of $\mu$ declines and the values of $S K E W, \rho$ and $M_{14}$ rise. The fact that there are industries in Table III for which this is clearly not the case confirms the existing difference between measuring developments of the firm-size distribution and developments of concentration.

In Figures 1 through 5 the weighted averages ${ }^{8}$ of $\mu, S K E W, \rho, M_{14}$ and GINI for the manufacturing industries and non-manufacturing industries over the years 1978-1989 are presented. It is clear that the year 1986 represents a reversal in trend for the measures of the location and shape of the firm-size distribution for manufacturing and non-manufacturing. After that year a turn towards larger firm sizes appears. Figure 5 also indicates a reversal in trend for the Gini-coefficient for manufacturing industries, but this occurs already in 1984. The declining average number of employees for manufacturing industries confirms the view that the share of small firms in manufacturing has risen over the entire period, despite the kink in 1986. The measures SKEW and $M_{14}$ also point in this direction.

\section{Developments of the individual industries}

In this section the development of the firm-size distribution will be considered for the industries separately. This will give a better understanding of the development of the four measures as presented in Figures 1 through 4.

In Table IV we see in which year the decline in $\mu$ changes into a rise. Two of the 16 manufacturing industries still had a declining value of $\mu$ in 1989 . These industries are the manufacture of textiles (ISIC 321) and instrument engineering (ISIC 385). For the manufacture of textiles (ISIC 321) this

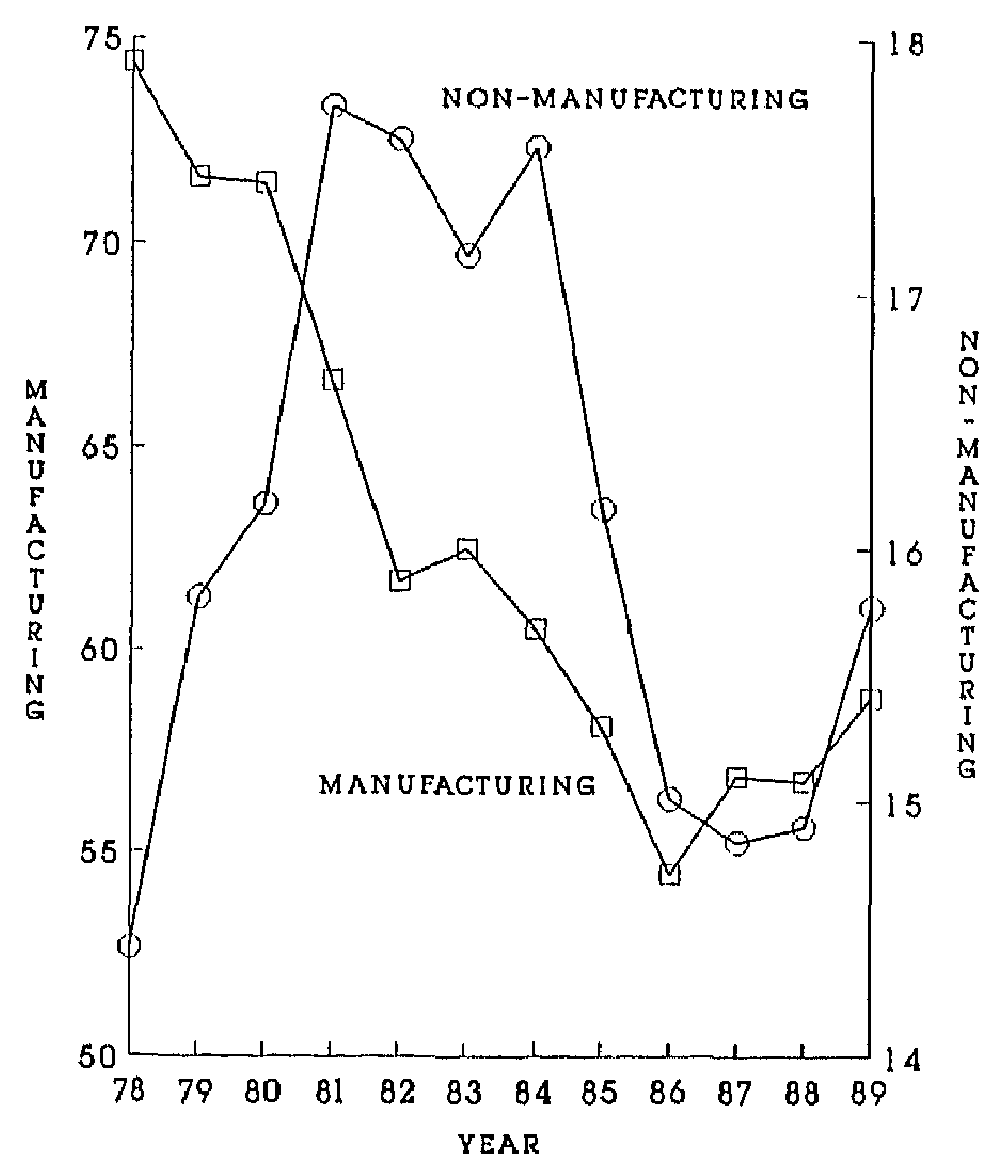

Fig. 1. Development of weighted average of $\mu$.

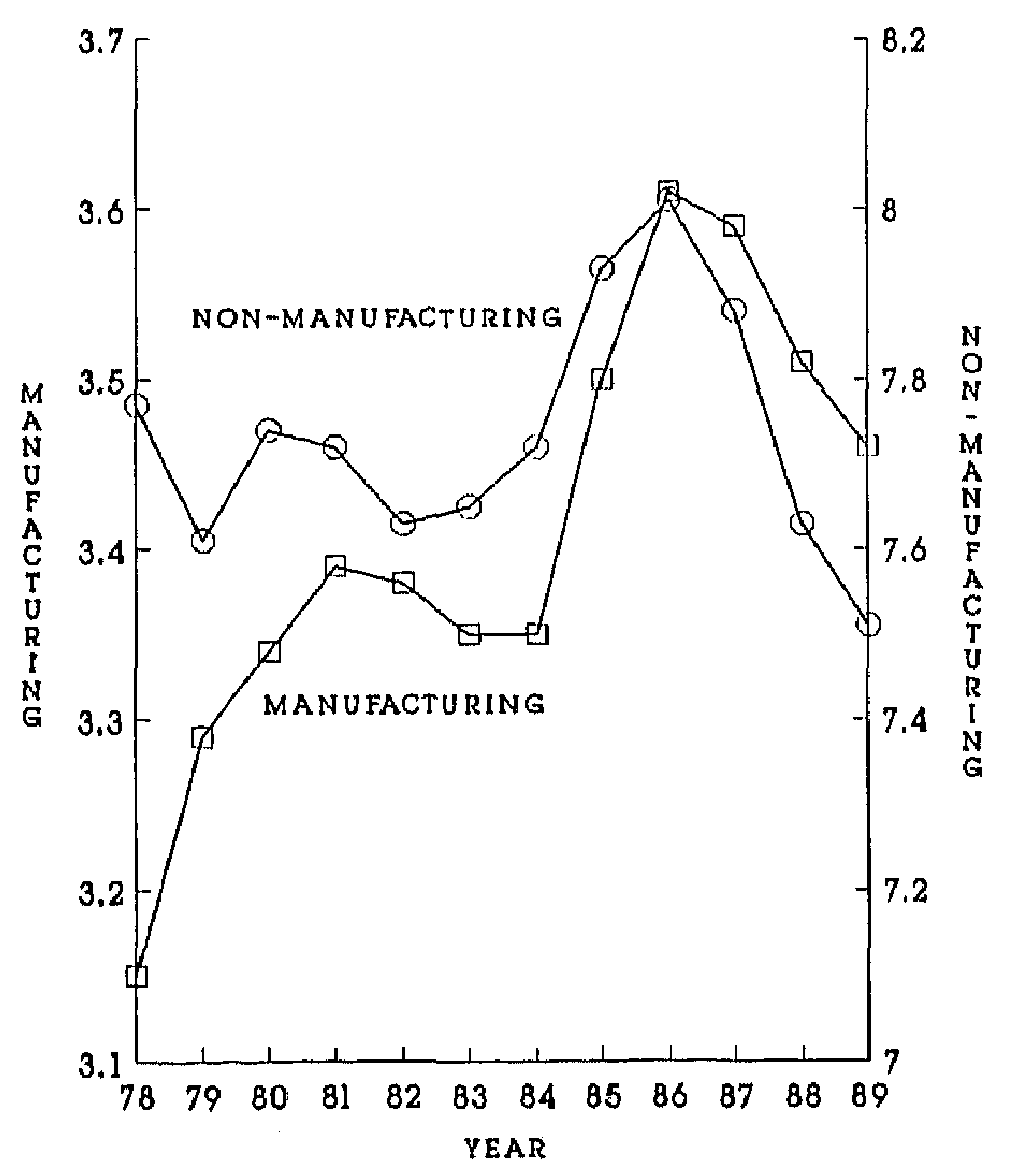

Fig. 2. Development of weighted average of $S K E W$. 


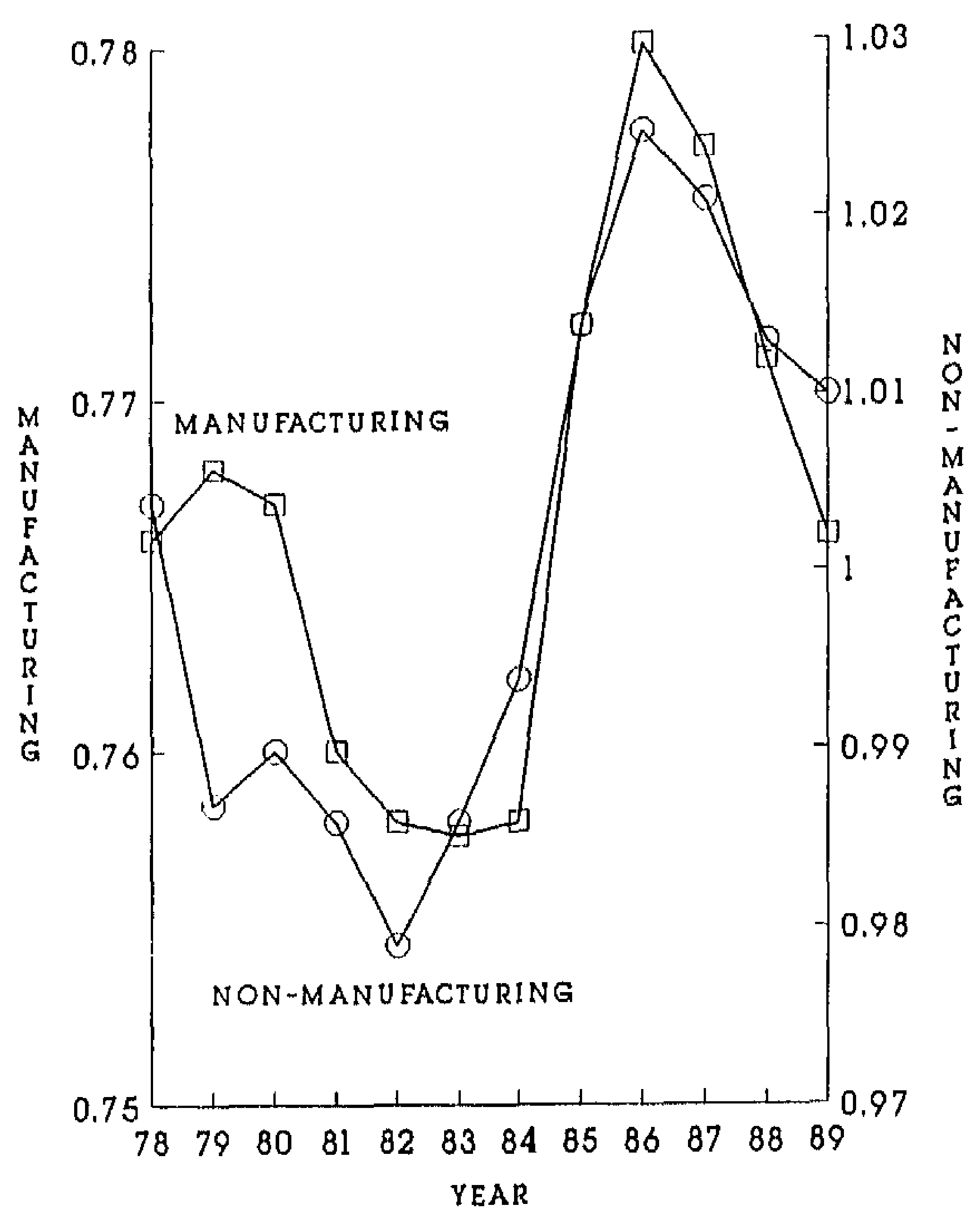

Fig. 3. Development of weighted average of $\rho$.

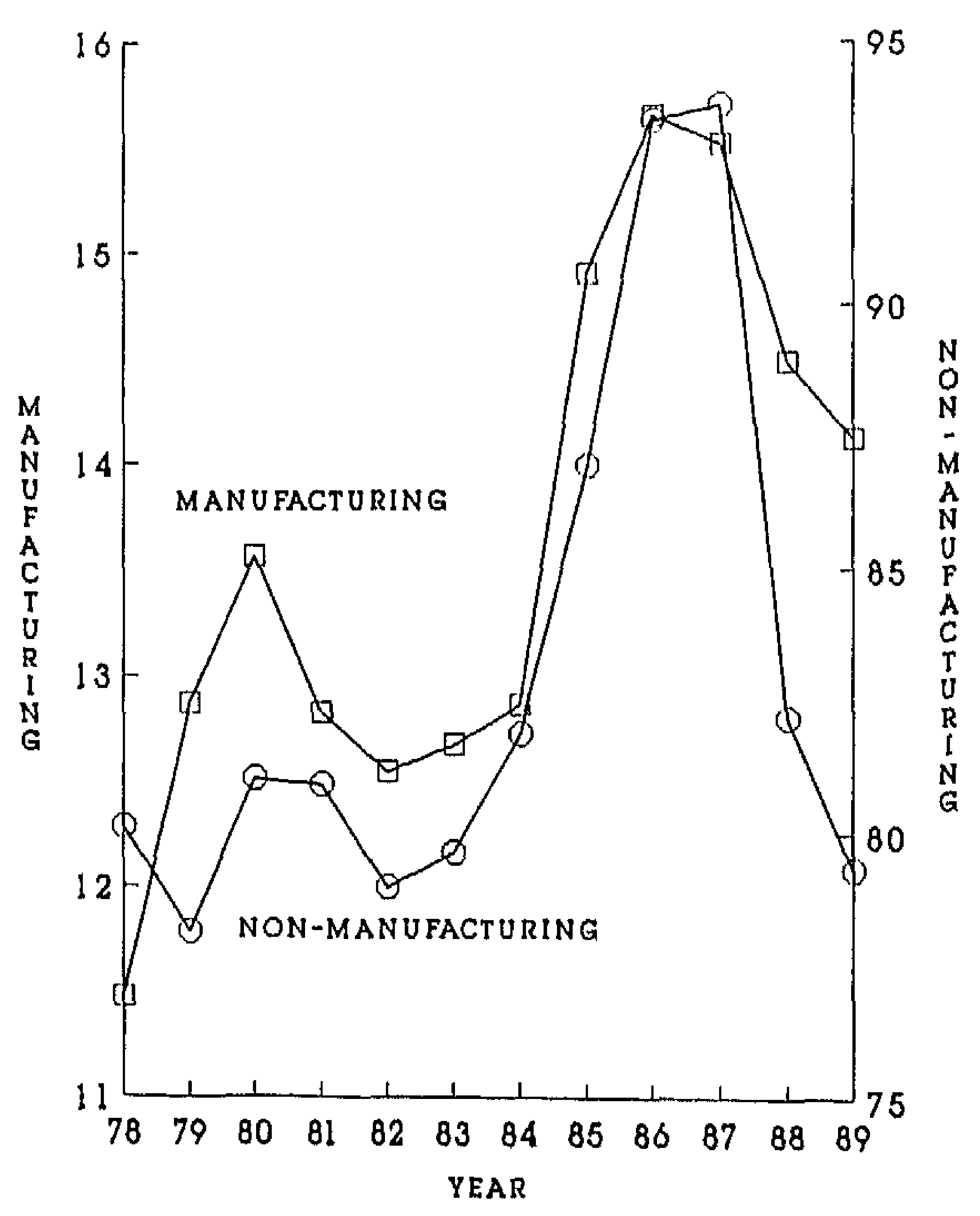

Fig. 4. Development of weighted average of $M_{14}$.

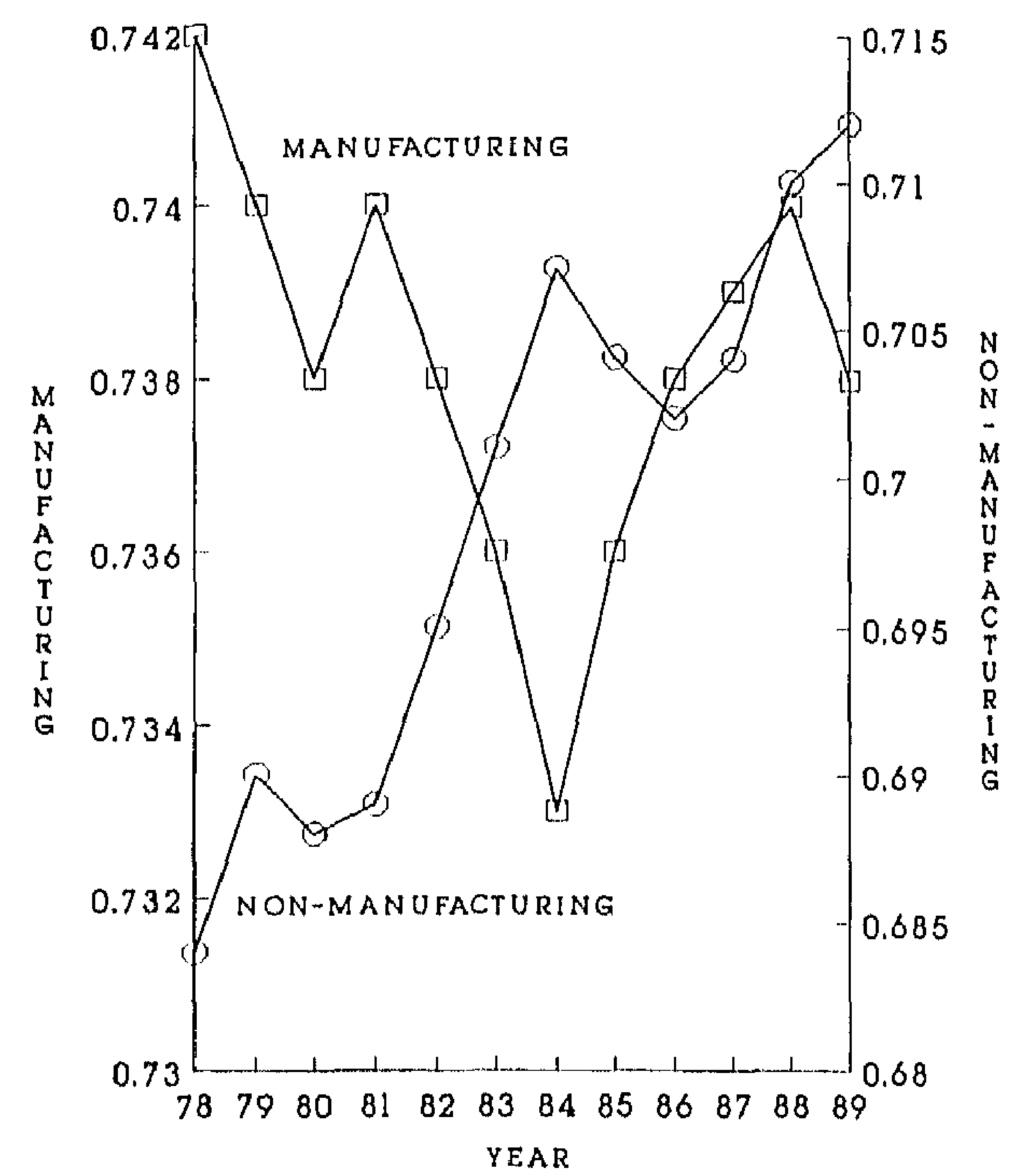

Fig. 5. Development of weighted average of GINI.

continuing decline can be explained by the continuing bad perspectives of mass-production of textiles in developed economies. The other industries had a turning point in the development of $\mu$ around 1986 with the exception of the chemical industry (ISIC 351/2) which already had a turning point in 1981. ${ }^{9}$ For the non-manufacturing industries two groups can be distinguished: seven industries have a minimum in the period 1978-1981 and eight industries in the period 1985-1988. We observe that a non-manufacturing industry has either a general decreasing part of small firms or a turning point around 1986, like most manufacturing industries. Further research should concentrate on whether the latter industries have one or more characteristics in common with the manufacturing industries. At first glance, we find that industries which depend highly on industrial activities like construction (ISIC 50) and transport (ISIC 711, 7121/3, 719) indeed have a turning point near 1986.

\section{Discussion}

There has been a tendency towards a lower 
TABLE IV

Occurrence of turning point in $\mu$

\begin{tabular}{|c|c|c|c|}
\hline ISIC & $\mu(1978)$ & $\mu_{\min }$ (year) & $\mu(1989)$ \\
\hline 31 & 24.3 & $22.3(1984)$ & 26.8 \\
\hline 321 & 54.8 & $34.9(1989)$ & 34.9 \\
\hline 322 & 23.2 & $12.9(1988)$ & 13.3 \\
\hline $323 / 4$ & 19.5 & $13.6(1987)$ & 16.0 \\
\hline 33 & 12.9 & $10.7(1986)$ & 10.9 \\
\hline 341 & 88.0 & 74.8 (1984) & 85.0 \\
\hline 342 & 24.2 & 18.9 (1987) & 19.8 \\
\hline $351 / 2$ & 154.6 & 141.4 (1981) & 165.8 \\
\hline $355 / 6$ & 45.8 & $30.1(1986)$ & 35.9 \\
\hline 36 & 33.0 & $26.2(1986)$ & 31.2 \\
\hline 381 & 19.5 & $17.5(1985)$ & 20.0 \\
\hline 382 & 44.9 & $31.6(1987)$ & 33.0 \\
\hline 383 & 263.4 & 123.1 (1988) & 124.9 \\
\hline 384 & 49.7 & 45.4 (1987) & 46.5 \\
\hline 385 & 20.4 & $13.4(1989)$ & 13.4 \\
\hline 39 & 15.8 & $13.9(1984)$ & 16.7 \\
\hline 50 & 13.4 & $11.2(1986)$ & 12.9 \\
\hline 50 & 12.1 & $9.9(1985)$ & 12.2 \\
\hline 61 & 12.1 & $10.4(1986)$ & 10.8 \\
\hline 62 & 6.2 & $6.2(1978)$ & 7.1 \\
\hline 63 & 3.8 & $3.8(1978)$ & 4.5 \\
\hline 711 & 15.6 & $14.8(1986)$ & 16.6 \\
\hline $7121 / 3$ & 84.9 & $52.4(1988)$ & 71.7 \\
\hline 719 & 16.2 & $13.4(1987)$ & 14.0 \\
\hline 81 & 35.3 & $35.3(1978)$ & 47.9 \\
\hline 82 & 20.9 & $17.4(1981)$ & 22.5 \\
\hline 831 & 5.5 & $5.1(1980)$ & 6.3 \\
\hline 832 & 13.2 & $13.0(1985)$ & 16.9 \\
\hline 833 & 6.9 & $6.5(1979)$ & 7.6 \\
\hline 9 & 14.5 & $14.5(1978)$ & 16.6 \\
\hline 951 & 7.7 & $6.1(1987)$ & 6.3 \\
\hline
\end{tabular}

Note: The variable $\mu_{\min }$ stands for the minimum value of $\mu$ in the period 1976-1989. The year between parentheses is the year in which this minimum is reached.

average firm size in manufacturing industries in the Netherlands until about 1986. After this year we observe an opposite tendency. Results for the non-manufacturing industries show no clear development of the firm-size distribution until about 1986, but reveal a rise in the share of larger firms after 1986. It should be noted that we investigated the firm-size distributions in terms of employment. The overall picture could be different when using data on sales volume or added value.

With regard to the decline of average firm size until 1986, Brock and Evans (1989) give six reasons for the reverse of the upward trend in average firm size until the late 1970s." They refer to the development of new products and processes, the reduction of scale economies due to technological changes, the greater importance of flexibility because of increasing competition, the increasing labour supply and falling real wages, the increasing demand for speciality products, and the relaxation of entry regulations.

Most of these points are more valid for manufacturing than for non-manufacturing industires and probably some of the points become less meaningful towards the late 1980s. There are some reasons for the turning point in the development of the share of small firms to occur around 1986. First, in 1992 the 12 countries of the EEC will form a common market. This may already have had a strong effect in the late 1980s and particularly from 1986 when most decisions on the future European integration were taken. The common market will probably lead to a higher degree of concentration and more resemblance in the firm-size distribution across countries. ${ }^{11} \mathrm{Sec}-$ ond, some small firms out of the many which started in the recovery period 1983-1986, grew into larger employment-size classes in the period 1986-1989.12 Related to this development is the additional entry of large-sized firms by aquisitions, mergers and foreign investments. ${ }^{13}$ Third, contrary to the early 1980s tight labour markets and rising real wages entered more and more in the late 1980s. Small firms generally have a higher labourcapital ratio than larger firms and therefore suffer more from rising wages.

\section{Notes}

* This study is part of a research program carried out at the Centre for Advanced Small Business Economics (CASBEC) of the Erasmus University Rotterdam. The authors are grateful to Jan van Dalen, Aad Kleijweg, Jeroen Potjes and Wim Verhoeven for helpful comments and Herman van Schaik for elaborating the original data files. The authors acknowledge a research grant from the "Stichting KMOfonds".

1 Carlsson (1989) showed that the average firm size declined in engineering industries from 1973 to 1983 for Denmark, Finland, Italy, Japan, the United Kingdom, the United States, and West Germany. The only exception was Sweden, which had a small rise in average firm size. Other evidence is shown by Acs and Audretsch (1989a) for U.S. metalworking industries and Sato (1989) for Japanese manufacturing,

${ }^{2}$ By employees we mean full-time equivalents (f.t.e.) in this study. 
${ }^{3}$ In our analysis we use an interpolation of the employment figures for the intermediate years and an extrapolation for 1988 and 1989.

4 We adjusted for the presence of firms with no employees by adding one employee to every firm and using the discrete Pareto distribution from two employees onwards.

5 The Gini-coefficient has a simpler expression when data on all $n$ firms in an industry are available. In that case, the coefficient equals $1-2\left(\sum_{i=1}^{n} i s_{i}-1\right) / n$, where $s_{i}$ is the share of firm $i$ in total employment.

6 Recent investigation in the explanation of the variation of the average firm size over the industries is performed in Acs and Audretsch (1989b), Schwalbach (1989) and White (1982).

7 The results for the engineering industries (ISIC 381-385) confirm the results of Carlsson (1989) for the Netherlands. See also Note 1.

8 The averages are weighted with the share in the total employment of the 31 industries. This implies that capitalintensive industries have relatively low weights.

9 The chemical industry is particularly heterogeneous in view of the fact that it contains not only very large-scaled bulkindustry, but also highly specialized small-scale parts, e.g. cosmetics.

10 See also Acs and Audretsch (1990).

11 Sleuwaegen and Yamawaki (1988) discuss the effect of the formation of the European Common Market on the degree of seller concentration. They conclude that the formation of the Common Market has created a more concentrated industry structure in the national market for Belgium, France, Italy and West Germany.

12 This is in accordance with the concept of life cycles in industries. Brock and Evans (1989) use the following formulation of this phenomenon: "If the formation and growth of small business is due to the development of new products or technologies, then history teaches us that, over time, only a handful of the firms in these new industries will survive" ( $p$. $10)$.

1.3 Additionally, the interest in the deglomeration of large firms is discouraged by the worsening stock market perspec- tives. The growing importance of deglomeration until 1986, evoked by the economic depression of the early 1980s, is therefore reduced. See Amsterdamse Investeringsbank NV (1990), where a turning point in 1986 is found with a different data set.

\section{References}

Acs, Z. J. and D. B. Audretsch, 1989a, 'Editors' Introduction', Small Business Economics 1, 1-5.

Acs, Z. J. and D. B. Audretsch, 1989b, 'Entrepreneurial Strategy and the Presence of Small Firms', Small Business Economics 1, 193-213.

Acs, Z. J. and D. B. Audretsch, 1990, The Economics of Small Firms: A European Challenge, Dordrecht: Kluwer Academic Publishers, pp. 1-22.

Amsterdamse Investeringsbank NV, 1990, 1980-1990. Verzelfstandigingen in Nederland, Amsterdam.

Brock, W. A. and D. S. Evans, 1989, 'Small Business Economics', Small Business Economics 1, 7-20.

Carlsson, B., 1989, 'The Evolution of Manufacturing Technology and Its Impact on Industrial Structure: An International Study', Small Business Economics 1, 21-37.

Ijiri, Y. and H. A. Simon, 1977, Skew Distributions and the Sizes of Business Firms, Amsterdam: North-Holland Publishing Company.

Sato, Y., 1989, 'Small Business in Japan: A Historical Perspective', Small Business Economics 1, 121-128.

Schwalbach, J., 1989, 'Small Business in German Manufacturing', Small Business Economics 1, 129-136.

Sleuwaegen, L. and H. Yamawaki, 1988, 'The Formation of the European Common Market and Changes in Market Structure and Performance', European Economic Review 32, 1451-1475.

White, L. J., 1982, 'The Determinants of the Relative Importance of Small Business', The Review of Economics and Statistics 64, 42-49. 